\title{
Front Matter: Volume 7022
}

, "Front Matter: Volume 7022," Proc. SPIE 7022, Advanced Laser Technologies 2007, 702201 (11 June 2008); doi: 10.1117/12.804453

SPIE. Event: Advanced Laser Technologies 2007, 2007, Levi, Finland 


\title{
PROCEEDINGS OF SPIE
}

\section{Advanced Laser Technologies 2007}

\author{
Ivan A. Shcherbakov \\ Chair \\ Risto Myllylä \\ Alexander V. Priezzhev \\ Matti Kinnunen \\ Vladimir I. Pustovoy \\ Mikhail Yu. Kirillin \\ Alexey P. Popov \\ Editors
}

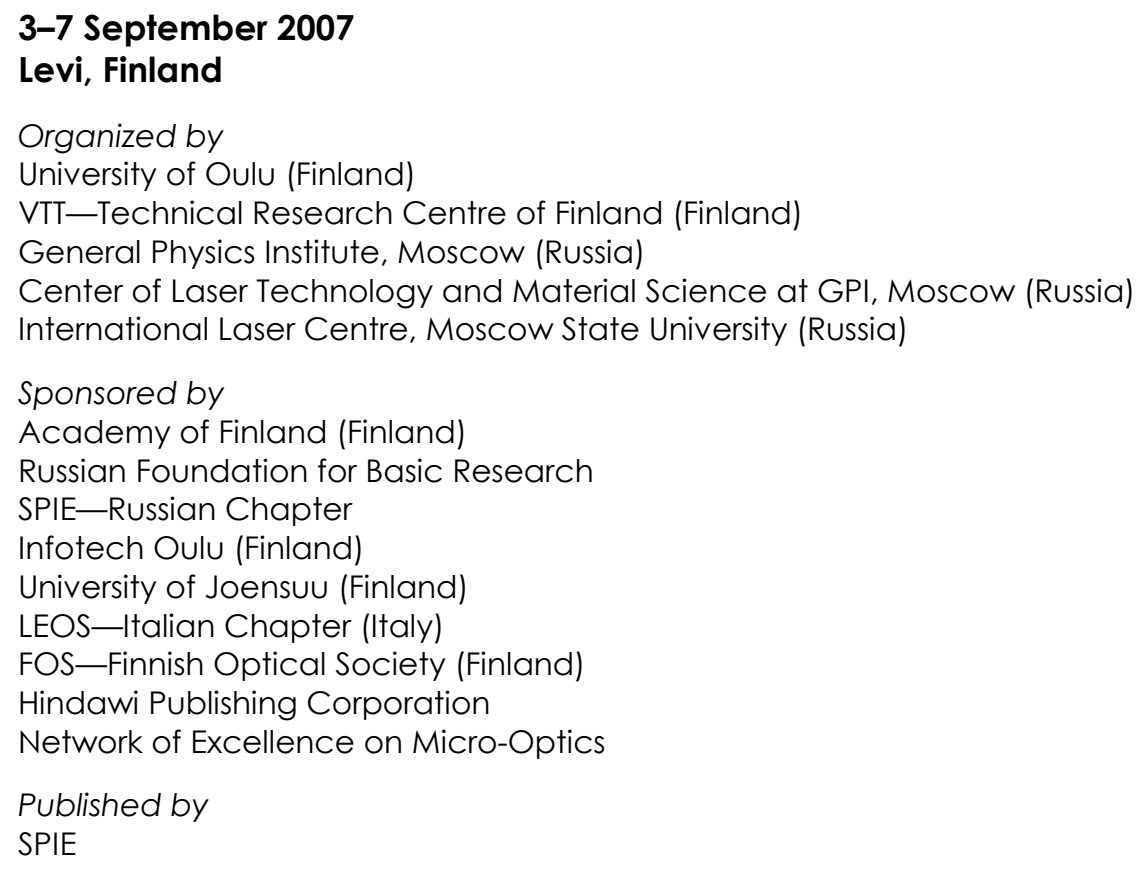


The papers included in this volume were part of the technical conference cited on the cover and title page. Papers were selected and subject to review by the editors and conference program committee. Some conference presentations may not be available for publication. The papers published in these proceedings reflect the work and thoughts of the authors and are published herein as submitted. The publisher is not responsible for the validity of the information or for any outcomes resulting from reliance thereon.

Please use the following format to cite material from this book:

Author(s), "Title of Paper," in Advanced Laser Technologies 2007, edited by Risto Myllylä, Alexander V. Priezzhev, Matti Kinnunen, Vladimir I. Pustovoy, Mikhail Yu. Kirillin, Alexey P. Popov, Proceedings of SPIE Vol. 7022 (SPIE, Bellingham, WA, 2008) Article CID Number.

ISSN 0277-786X

ISBN 9780819472359

Published by

SPIE

P.O. Box 10, Bellingham, Washington 98227-0010 USA

Telephone +1 3606763290 (Pacific Time) · Fax +1 3606471445

SPIE.org

Copyright (c) 2008, Society of Photo-Optical Instrumentation Engineers

Copying of material in this book for internal or personal use, or for the internal or personal use of specific clients, beyond the fair use provisions granted by the U.S. Copyright Law is authorized by SPIE subject to payment of copying fees. The Transactional Reporting Service base fee for this volume is $\$ 18.00$ per article (or portion thereof), which should be paid directly to the Copyright Clearance Center (CCC), 222 Rosewood Drive, Danvers, MA 01923. Payment may also be made electronically through CCC Online at copyright.com. Other copying for republication, resale, advertising or promotion, or any form of systematic or multiple reproduction of any material in this book is prohibited except with permission in writing from the publisher. The CCC fee code is 0277-786X/08/\$18.00.

Printed in the United States of America.

Publication of record for individual papers is online in the SPIE Digital Library.

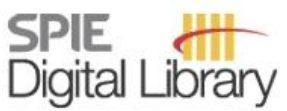

SPIEDigitalLibrary.org

Paper Numbering: Proceedings of SPIE follow an e-First publication model, with papers published first online and then in print and on CD-ROM. Papers are published as they are submitted and meet publication criteria. A unique, consistent, permanent citation identifier (CID) number is assigned to each article at the time of the first publication. Utilization of CIDs allows articles to be fully citable as soon they are published online, and connects the same identifier to all online, print, and electronic versions of the publication. SPIE uses a six-digit CID article numbering system in which:

- The first four digits correspond to the SPIE volume number.

- The last two digits indicate publication order within the volume using a Base 36 numbering system employing both numerals and letters. These two-number sets start with 00, 01, 02, 03, 04, 05, $06,07,08,09,0 \mathrm{~A}, 0 \mathrm{~B} \ldots \mathrm{OZ}$, followed by $10-1 \mathrm{Z}, 20-2 \mathrm{Z}$, etc.

The CID number appears on each page of the manuscript. The complete citation is used on the first page, and an abbreviated version on subsequent pages. Numbers in the index correspond to the last two digits of the six-digit CID number. 


\section{Contents}

ix Conference Committee
xiii Introduction

\section{NANOPHOTONICS}

702202 Manufacturing of periodical nanostructures by fs-laser direct writing [7022-01]

J. Gottmann, D. Wortmann, R. Wagner, RWTH Aachen (Germany)

\section{BIOPHOTONICS I}

702203 Diffractive optical element spectroscopy of biomaterial surface [7022-02]

V. Vetterl, Institute of Biophysics (Czech Republic) and Masaryk Univ. (Czech Republic); S. Hasoň, Institute of Biophysics (Czech Republic); H. Tuononen, M. Silvennoinen, Univ. of JoensuU (Finland); K. Myller, MGM-Devices Ltd. (Finland); J. Vaněk, Masaryk Univ. (Czech Republic); R. Silvennoinen, Univ. of Joensuu (Finland)

\section{BIOPHOTONICS II}

702204 New efficient near-IR photosensitizer based on bacteriochlorin $\mathrm{p} \mathrm{N}$-methoxycycloimide oxyme methyl ester [7022-03]

I. G. Meerovich, N.N. Blokhin Russian Cancer Research Ctr. (Russia); M. A. Grin,

A. G. Tsyprovskiy, M. V. Lomonsov Moscow State Academy of Fine Chemical Technology (Russia); G. A. Meerovich, General Physics Institute (Russia); N. A. Oborotova, N.N. Blokhin Russian Cancer Research Ctr. (Russia); V. B. Loschenov, General Physics Institute (Russia); A. Yu. Baryshnikov, N.N. Blokhin Russian Cancer Research Ctr. (Russia); A. F. Mironov, Moscow State Academy of Fine Chemical Technology (Russia)

702205 Multi-spectral imaging of oxygen saturation [7022-04]

T. A. Savelieva, A. A. Stratonnikov, V. B. Loschenov, General Physics Institute (Russia)

702206 The video fluorescent device for diagnostics of cancer of human reproductive system [7022-05]

N. N. Brysin, K. G. Linkov, A. A. Stratonnikov, T. A. Savelieva, V. B. Loschenov, General Physics Institute (Russia)

\section{LASER-MATTER INTERACTION}

702207 Analysis of the diffuse light and optacoustic signal generation in nanoparticles (Invited Paper) [7022-06]

H. Lamela, V. Cunningham, P. Pedreira, D. C. Gallego, P. Acedo, Univ. Carlos III de Madrid (Spain); W. Fritzsche, A. Csaki, G. Festag, A. Steinbrük, Institut für Photonische Technologien (Germany) 
702208 Laser micro-drilling with nanoseconds: parametrical influences and results [7022-07] R. Witte, T. Moser, R. Liebers, R. Holtz, Lasag AG (Switzerland)

BIOPHOTONICS III

702209 Monte Carlo study of skin optical clearing to enhance light penetration in the tissue: implications for photodynamic therapy of acne vulgaris [7022-08]

A. N. Bashkatov, E. A. Genina, V. V. Tuchin, Saratov State Univ. (Russia); G. B. Altshuler, I. V. Yaroslavsky, Palomar Medical Technology, Inc. (USA)

7022 OA Effective phase function of light scattered at small angles by polydisperse particulate media [7022-09]

I. Turcu, National Institute for Research and Development of Isotopic and Molecular Technologies (Romania)

\section{NONLINEAR OPTICS}

$7022 \mathrm{OB}$ Optical orientation of dipolar centers in $\mathrm{Bi}_{12} \mathrm{SiO}_{20}$ crystal grown in an oxygen-free atmosphere [7022-10]

A. I. Grachev, A.F. Ioffe Physico-Technical Institute (Russia); E. Nippolainen, A. A. Kamshilin, Univ. of Kuopio (Finland)

\section{PHOTOACOUSTIC AND ULTRASONIC TECHNIQUES}

7022 OC Investigation of the photoacoustic signal dependence on laser power [7022-11]

J. Niemi, T. Löfqvist, P. Gren, Lulea Univ. of Technology (Sweden)

7022 OD Pulsed laser photoacoustic monitoring of paper pulp consistency [7022-12]

Z. Zhao, M. Törmänen, R. Myllylä, Univ. of Oulu (Finland)

\section{LASER IMAGING AND MEASUREMENT TECHNIQUES}

7022 OE Image processing of real-world three-dimensional objects sensed with digital holography (Invited Paper) [7022-13]

C. P. McElhinney, B. M. Hennelly, National Univ. of Ireland/Maynooth (Ireland);

T. J. Naughton, National Univ. of Ireland/Maynooth (Ireland) and Univ. of Oulu (Finland)

7022 OF Demodulation of fiber Bragg grating wavelength shifts by optical feedback interferometry [7022-14]

H. C. Seat, M. Suleiman, T. Bosch, Lab. d'Optoélectronique pour les Systèmes Embarqués, ENSEEIHT-INPT (France)

7022 OG The detection of knots in wood materials using the tracheid effect [7022-15] I. P. Jolma, A. J. Mäkynen, Univ. of Oulu (Finland)

$7022 \mathrm{OH}$ Mitigation of the back-reflection disturbances in semiconductor lasers taking advantage of the self-mixing signal properties [7022-16]

E. M. Randone, S. Donati, Univ. of Pavia (Italy) 
7022 Ol Subnanometer characterization of large aperture optical components using broad-band interferometry (Invited Paper) [7022-17]

A. M. Sergeev, E. A. Khazanov, I. E. Kozhevatov, D. E. Silin, Institute of Applied Physics (Russia)

7022 0J Advanced diode-pumped alkali lasers (Invited Paper) [7022-18]

B. V. Zhdanov, R. J. Knize, Air Force Academy (USA)

7022 OK Passively stabilized Kerr-lens mode-locked diode-pumped Yb:YAG laser [7022-19]

S. Uemura, K. Torizuka, National Institute of Advanced Industrial Science and Technology (Japan)

$7022 \mathrm{OL}$ Femtosecond lasers: potential tools for manufacturing high-frequency negative refractive materials [7022-20]

R. Dabu, M. Zamfirescu, M. Dumitru, I. Anghel, National Institute for Lasers, Plasma, and Radiation Physics (Romania)

$70220 \mathrm{M} \quad 10 \mathrm{kHz} 54 \mathrm{~W}$ Ti:sapphire regenerative amplifier as a pumping laser of a laser-plasma X-ray source [7022-21]

I. Matsushima, H. Yashiro, T. Tomie, National Institute of Advanced Industrial Science and Technology (Japan)

\section{BIOPHOTONICS IV}

7022 ON Novel laser technologies for human skin in-vivo assessment [7022-22]

J. Spigulis, A. Lihachev, L. Gailite, R. Erts, Univ. of Latvia (Latvia)

IMAGING TECHNIQUES

$702200 \quad$ A camera for a narrow and deep welding groove [7022-23]

M. S. Vehmanen, Univ. of Oulu (Finland); M. Korhonen, Hollming Works Oy (Finland);

A. J. Mäkynen, Univ. of Oulu (Finland)

7022 OP Thickness measurement using image sharpness-based range sensing [7022-24]

S. Tervonen, I. P. Jolma, A. Mäkynen, Univ. of Oulu (Finland)

7022 OQ Dynamic-speckle profilometer for online measurements of coating thickness [7022-25] A. A. Kamshilin, D. Semenov, E. Nippolainen, Univ. of Kuopio (Finland); S. Miridonov, CICESE (Mexico)

7022 OR Thickness measurement of thin wood material by differential laser triangulation method [7022-26]

J. M. Hattuniemi, A. J. Mäkynen, Univ. of Oulu (Finland) 
POSTER SESSION 1: BIOPHOTONICS

7022 OS 3D simulation of plant and living tissue superficial lesions [7022-27]

I. A. Bratchenko, A. R. Sindyaeva, V. P. Zakharov, Samara State Aerospace Univ. (Russia)

7022 OT Double integrating sphere system for optical parameter determination of industrial suspensions [7022-28]

V. T. J. Keränen, A. J. Mäkynen, Univ. of Oulu (Finland)

$7022 \mathrm{OU} \quad$ Experimental investigation of kinetics spectral characteristics of a plant tissue [7022-29] V. P. Zakharov, Samara State Aerospace Univ. (Russia); E. V. Vorobjova, Samara State Aerospace Univ. (Russia) and P.N. Lebedev Physics Institute, Samara (Russia); S. P. Kotova, P.N. Lebedev Physics Institute, Samara (Russia); P. E. Timchenko, Samara State Aerospace Univ. (Russia)

7022 OV Physical methods for studying the effect of copper and cadmium ions on protein solutions [7022-30]

A. V. Boiko, G. P. Petrova, Y. M. Petrusevich, D. I. Ten, I. A. Perfil'eva, S. S. Koshel,

D. V. Matyushenko, M. V. Lomonosov State Univ. (Russia)

7022 OW Dynamic properties of collagen molecules in water and salt solutions [7022-31]

I. A. Perfil'eva, G. P. Petrova, Y. M. Petrusevich, A. V. Boiko, M. S. Ivanova, X. Zhang, Lomonosov Moscow State Univ. (Russia)

7022 OX Time gating in glucose sensing with ultrashort pulses [7022-32]

A. V. Bykov, M. V. Lomonosov Moscow State Univ. (Russia) and Univ. of Oulu (Finland); M. Yu. Kirillin, Univ. of Oulu (Finland); A. V. Priezzhev, M. V. Lomonosov Moscow State Univ. (Russia); R. Myllyla, Univ. of Oulu (Finland)

7022 OY Red blood cells in laser beam field: calculations of light scattering [7022-33]

A. E. Lugovtsov, A. V. Priezzhev, S. Yu. Nikitin, M. V. Lomonosov Moscow State Univ. (Russia)

$70220 Z$ About in-situ functionalization of carbon nanopowder synthesized by laser-induced pyrolysis [7022-34]

L. Gavrila-Florescu, I. Sandu, I. Soare, M. Scarisoreanu, E. Popovici, I. Morjan, I. Voicu, National Institute for Lasers, Plasma and Radiation Physics (Romania)

\section{POSTER SESSION 2: NANOPHOTONICS}

702210 Influence of vesicle size distribution on level and selectivity of accumulation of liposomal photosensitizer Tiosens in tumor [7022-35]

G. A. Meerovich, General Physics Institute (Russia); I. G. Meerovich, N.N. Blokhin Russian Cancer Research Ctr. (Russia); D. G. Gurevich, N.N. Blokhin Russian Cancer Research Ctr. (Russia) and I.M. Sechenov Moscow Medical Academy (Russia); S. I. Vorobyov, M.V. Lomonsov Moscow State Academy of Fine Chemical Technology (Russia); V. G. Pevgov, M.V. Chrunitchev State Cosmonautic Research and Production Ctr. (Russia);

Z. S. Smirnova, N. A. Oborotova, N.N. Blokhin Russian Cancer Research Ctr. (Russia); E. A. Lukyanets, State Scientific Ctr. NIOPIK (Russia); V. B. Loschenov, General Physics Institute (Russia); A. Yu. Baryshnikov, N.N. Blokhin Russian Cancer Research Ctr. (Russia) 
702211 Monte Carlo calculations of UV protective properties of emulsions containing $\mathrm{TiO}_{2}$, $\mathrm{Si}_{\text {, }}$ and $\mathrm{SiO}_{2}$ nanoparticles [7022-36]

A. P. Popov, Univ. of Oulu (Finland) and M.V. Lomonosov Moscow State Univ. (Russia);

A. V. Priezzhev, M.V. Lomonosov Moscow State Univ. (Russia); J. Lademann, Humboldt Univ. (Germany); R. Myllylä, Univ. of Oulu (Finland)

POSTER SESSION 3: LASER IMAGING, MEASUREMENTS, AND INTERFEROMETRY

702212 Full-field high-resolving optical coherence tomography system for evaluating paper materials [7022-37]

E. Alarousu, Univ. of Oulu (Finland); I. Gurov, N. Kalinina, A. Karpets, N. Margariants, St. Petersburg State Univ. of Information Technologies, Mechanics and Optics (Russia); R. Myllylä, T. Prykäri, Univ. of Oulu (Finland); E. Vorobeva, St. Petersburg State Univ. of Information Technologies, Mechanics and Optics (Russia)

702213 Monte Carlo method for simulating optical coherence tomography signal in homogeneous turbid media [7022-38]

F. Zhang, Qingdao Univ. (China); M. Kinnunen, A. Popov, R. Myllylä, Univ. of Oulu (Finland)

702214 Effect of paper porosity on OCT images: Monte Carlo study [7022-39]

M. Yu. Kirillin, Univ. of Oulu (Finland) and M.V. Lomonosov Moscow State Univ. (Russia);

A. V. Priezzhev, M. V. Lomonosov Moscow State Univ. (Russia); R. Myllyla, Univ. of Oulu (Finland)

702215 Frequency spectrum analysis of pulsed photoacoustic signals in Intralipid [7022-41] M. Kinnunen, R. Myllylä, Univ. of Oulu (Finland)

702216 Analysis of accuracy of laser spot centroid estimation [7022-42]

R. Singh, J. M. Hattuniemi, A. J. Mäkynen, Univ. of Oulu (Finland)

702217 The possibilities for using $x$-ray radioscopy in thin wood inspection [7022-43]

T. H. Ervasti, A. J. Mäkynen, Measurement and Sensor Lab. (Finland)

702218 CALAS - Carpathian laser strainmeter: a project and preliminary results [7022-44]

F. Garoi, D. Apostol, V. Damian, P. C. Logofătu, B. F. Ioniță, National Institute for Laser Plasma and Radiation Physics (Romania); J. Lazar, Institute of Scientific Instruments (Czech Republic); G. Molesini, National Institute of Applied Optics (Italy); T. Papadopoulos, National and Kapodistrian Univ. of Athens (Greece); C. Ionescu, A. Țugui, National Institute for Earth Physics (Romania)

702219 Use of time-of-flight 3D camera in volume measurement [7022-45]

A. V. H. Ollikkala, A. J. Mäkynen, Univ. of Oulu (Finland)

$70221 \mathrm{~A}$ Optical object detection in paper improved by refractive index matching and mechanical treatment [7022-46]

J. Saarela, S. Heikkinen, Univ. of Oulu (Finland); T. Fabritius, Univ. of Oulu (Finland) and Univ. of Tsukuba (Japan); R. Myllylä, Univ. of Oulu (Finland) 
7022 1B Picosecond laser system based on microchip oscillator seed [7022-47]

R. Dabu, A. Stratan, C. Fenic, C. Blanaru, L. Rusen, National Institute for Lasers, Plasma and Radiation Physics (Romania)

7022 1C Correlation between mechanical properties of aluminum alloys and characteristics of laser-induced plasma [7022-48]

T. A. Labutin, A. M. Popov, D. N. Sychev, N. B. Zorov, Lomonosov Moscow State Univ. (Russia)

7022 1D Influence of ferrite surface microstructure on laser ablation [7022-49]

A. M. Popov, T. A. Labutin, V. V. Litvinova, N. B. Zorov, Lomonosov Moscow State Univ. (Russia)

$70221 \mathrm{E} \quad$ Femtosecond all-polarization-maintaining fiber laser operating at $1028 \mathbf{~ n m ~ [ 7 0 2 2 - 5 1 ] ~}$ R. K. Olsson, Technical Univ. of Denmark (Denmark); T. V. Andersen, L. Leick, NKT Research \& Innovation A/S (Denmark); V. Levitan, P. U. Jepsen, D. Turchinovich, Technical Univ. of Denmark (Denmark)

7022 if Thermal effects in the 2D and 3D laser material marking and coloring [7022-52] P. Sterian, E. Mocanu, Bucharest Polytechnic Univ. (Romania)

7022 1G Pulsed laser deposition and e-beam evaporation of vanadium dioxide thin films for IRphotonics applications [7022-53]

S. Heinilehto, J. Lappalainen, V. Lantto, H. Jantunen, Univ. of Oulu (Finland)

$70221 \mathrm{H}$ Standardless quantitative analysis of alloys by laser induced breakdown spectroscopy [7022-54]

V. N. Lednev, S. M. Pershin, General Physics Institute (Russia)

$702211 \quad$ Real time modal analysis using a strong feedback self mixing sensor [7022-55]

J. El Assad, T. Bosch, LOSE, ENSEEIHT, Univ. of Toulouse (France); G. Plantier, GSII, ESEO (France)

Author Index 


\title{
Conference Committee
}

\author{
Conference Chair
}

Ivan A. Shcherbakov, A.M. Prokhorov General Physics Institute (Russia)

Program Committee Cochairs

Vitaly Konov, A.M. Prokhorov General Physics Institute (Russia)

Alexander V. Priezzhev, M.V. Lomonosov Moscow State University (Russia)

Risto Myllylä, University of Oulu (Finland)

Organizing Committee Cochairs

Vladimir I. Pustovoy, A.M. Prokhorov General Physics Institute (Russia)

Jukka Hast, VTT (Finland)

Matti Kinnunen, University of Oulu (Finland)

Local Organizing Committee

Erkki Alarousu, University of Oulu (Finland)

Päivi Ronkainen, University of Oulu (Finland)

Mikhail Yu. Kirillin, University of Oulu (Finland)

Alexey P. Popov, University of Oulu (Finland)

International Program Committee

Sergey Bagaev, Institute of Laser Physics (Russia)

Thierry Bosch, ENSEEIHT-INPT (France)

Jan Boyd, Imperial College London (United Kingdom)

Valentin Craciun, University of Florida (USA)

Friedrich Dausinger, University of Stuttgart (Germany)

Silvano Donati, University of Pavia (Italy)

Dan Dumitras, National Institute for Laser, Plasma and Radiation Physics

(Romania)

Costas Fotakis, Foundation for Research and Technology Hellas (Greece)

Sergey V. Garnov, A.M. Prokhorov General Physics Institute (Russia)

Anna Giardini, Università La Sapienza di Roma (Italy)

Richard Haglund, Vanderbilt University (USA)

Peter Herman, University of Toronto (Canada)

Timo Jääskeläinen, University of JoensuU (Finland)

Pavel K. Kashkarov, M.V. Lomonosov Moscow State University (Russia)

Harri Kopola, VTT (Finland)

Horacio Lamela, University Carlos III of Madrid (Spain)

Armando Luches, University of Lecce (Italy)

Qingming Luo, Huazhong University of Science and Technology (China) 
Torbjörn Löfqvist, Luleå University of Technology (Sweden)

Eva Majkova, Institute of Physics (Slovakia)

Vladimir A. Makarov, M.V. Lomonosov Moscow State University (Russia)

Vladislav Panchenko, Institute on Laser and Information Technologies (Russia)

Markus Pessa, Tampere University of Technology (Finland)

Alberto Pique, Naval Research Laboratory (USA)

Adrian Podoleanu, University of Kent at Canterbury (United Kingdom)

Bouchta Sahraoui, University of Angers (France)

Alexander Sergeev, Institute of Applied Physics (Russia)

Michael Stuke, Max-Planck-Institut, Gottingen (Germany)

Valery V. Tuchin, Saratov State University (Russia)

Vadim P. Veiko, St. Petersburg State University of Information Technologies (Russia)

Ernst Wintner, Vienna University of Technology (Austria)

Kexin Xu, Tianjin University (China)

Alexey M. Zheltikov, M.V. Lomonosov Moscow State University (Russia)

\section{Session Chairs}

Plenary Session I

Alexey M. Zheltikov, M.V. Lomonosov Moscow State University (Russia)

Plenary Session II

Valery V. Tuchin, Saratov State University (Russia)

Plenary Session III

Timo Jääskeläinen, University of JoensuU (Finland)

Plenary Session IV

Sergey V. Garnov, A.M. Prokhorov General Physics Institute (Russia)

Biophotonics I

Alexander V. Priezzhev, M.V. Lomonosov Moscow State University (Russia)

Qingming Luo, Huazhong University of Science and Technology (China)

Biophotonics II

Igor V. Meglinski, Cranfield University (United Kingdom)

Scott A. Prahl, Oregon Medical Laser Center (USA)

Biophotonics III

Karsten König, Fraunhofer Institute of Biomedical Technology (Germany)

Jürgen Lademann, Charité-Universitätsmedizin Berlin (Germany)

Biophotonics IV

Alexander A. Stratonnikov, A.M. Prokhorov General Physics Institute (Russia)

Zuomin Zhao, University of Oulu (Finland) 
Imaging Techniques

Vitaly B. Voloshinov, M.V. Lomonosov Moscow State University (Russia)

Laser imaging and Measurement Techniques

Dmitry A. Zimnyakov, Saratov State University (Russia)

Silvano Donati, Università di Pavia (Italy)

Laser-Matter Interaction I

Vyacheslav B. Morozov, M.V. Lomonosov Moscow State University (Russia)

Raimo Silvennoinen, University of JoensuU (Finland)

Lasers and Laser-Matter Interaction II

Frank Wyrowski, University of Jena (Germany)

Tamas Szörenyi, University of Szeged (Hungary)

Lasers and Laser Systems

Kai-Erik Peiponen, University of JoensuU (Finland)

Dan Dumitras, National Institute for Laser, Plasma and Radiation Physics (Romania)

Nanophotonics I

Victor Yu. Timoshenko, M.V. Lomonosov Moscow State University (Russia)

Vadim P. Veiko, St. Petersburg State University of Information Technologies (Russia)

Nanophotonics II

Vladimir I. Pustovoy, A.M. Prokhorov General Physics Institute (Russia)

Non-linear Optics

Vladimir I. Emelianov, M.V. Lomonosov Moscow State University (Russia)

Boris V. Zhdanov, US Air Force Academy (USA)

Photoacoustic and Ultrasonic Techniques

Torbjörn Löfqvist, Luleå University of Technology (Sweden)

Poster Session I

Meng Wang, University of Oulu (Finland)

Poster Session II

Meng Wang, University of Oulu (Finland)

Poster Session III

Mikko Juuti, University of Joensuu (Finland)

Poster Session IV

Mikko Juuti, University of Joensuu (Finland) 
Downloaded From: https://www.spiedigitallibrary.org/conference-proceedings-of-spie on 26 Apr 2023

Terms of Use: https://www.spiedigitallibrary.org/terms-of-use 


\section{Introduction}

Advanced Laser Technologies 2007 (ALT-2007) was held in Levi, Finland, September 3-7, 2007. This conference followed the traditions of the previous 14 ALT conferences held once a year in different countries since 1993, and focused on the recent developments and advances in laser technologies and their applications.

Like all preceding meetings of this series, this well-attended conference brought together a remarkable group of physicists and engineers from many countries of the world. They presented and vigorously discussed altogether 73 oral papers and 55 poster contributions. Fifty-three manuscripts, based on the work of those presentations, were selected to be published in this volume.

The key topics of ALT-2007 included but were not limited to nanophotonics, biophotonics, pico- and femtosecond laser pulses generation and applications, photoacoustics, optical tomography, lasers and laser systems, laser-matter interaction and nonlinear processes, smart sensors and optical MEMS, microoptics, and laser measurements.

The success of this and the preceding conferences on advanced laser technologies, and the noteworthy progress that is being made in this field by many research groups in different countries substantiate the necessity of further discussions of these and related topics at future meetings.

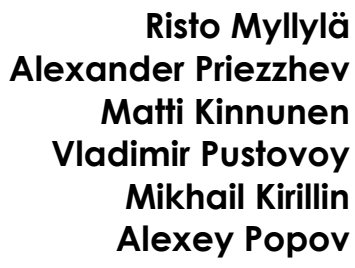


Downloaded From: https://www.spiedigitallibrary.org/conference-proceedings-of-spie on 26 Apr 2023

Terms of Use: https://www.spiedigitallibrary.org/terms-of-use 